\title{
The Effect of Benzyl Penicillin on the Ultrastructure of Neisseria gonorrhoeae
}

\author{
By J. J. JAMIL* AND S. HAFIZ \\ Department of Medical Microbiology, University of Sheffield Medical School, \\ Beech Hill Road, Sheffield S1O 2RX, U.K.
}

(Received 4 March 1981; revised 15 June 1981)

\begin{abstract}
Electron microscopy of Neisseria gonorrhoeae grown on solid medium with a subinhibitory concentration of penicillin suggested that the amount of penicillin reaching each pair of gonococci was different, as illustrated by the ultrastructural appearance of $N$. gonorrhoeae cells in the colony. This supports the view that the concentration of penicillin in different parts of the colony is not uniform, causing some cells to lyse while the others remain intact.
\end{abstract}

\section{INTRODUCTION}

Penicillin inhibits the final step of murein synthesis in bacteria, that is, the formation of cross-bridges between peptide side-chains of newly formed peptidoglycan strands and the peptide chains of the completed cell wall (Blumberg \& Strominger, 1974). At subinhibitory concentrations penicillin affects cell division, causing the cell to elongate and form bulges at sites where the septum would normally develop (Rogers, 1974), or inducing the formation of osmotically fragile spheroplasts as a result of inhibition of cell wall formation (Lederberg, 1956). Hugo \& Russell $(1960 a, b, 1961)$ showed that the loss of viability in Gram-negative organisms treated with penicillin differed from the incidence of spheroplast formation and concluded that the lethal effect of the drug was not a consequence of osmotic fragility.

In our earlier study (Jamil et al., 1981) of the effect of benzyl penicillin incorporated in either liquid or solid medium on strains of Neisseria gonorrhoeae, we observed that for each strain tested the minimum inhibitory concentration (m.i.c.) in liquid medium was consistent and was also consistent or higher on solid medium. In contrast, the minimum bactericidal concentration (m.b.c.) in liquid medium was found to be the same for all strains of $N$. gonorrhoeae tested, while on solid medium it was not the same for all strains tested. The differences in m.b.c. between liquid and solid medium could be due to the more uniform accessibility of bacteria to penicillin in liquid medium where it is in contact with every organism; on solid medium the penicillin concentration is dependent on diffusion and so is not exactly the same for every cell of the colony.

We decided to study the effect of penicillin in solid medium on the growth of gonococci by scanning and transmission electron microscopy.

\section{METHODS}

Organism and growth conditions. Neisseria gonorrhoeae strain AN 151, an isolate from Sheffield Special Clinic found to have the same m.i.c. and m.b.c., was used. The strain was grown on Difco GC medium with $2 \%(\mathrm{v} / \mathrm{v})$ defined supplement (Kellogg et al., 1963) in an atmosphere of $10 \%(\mathrm{v} / \mathrm{v}) \mathrm{CO}_{2}$ and increased humidity at $35-36^{\circ} \mathrm{C}$ for $24 \mathrm{~h}$. Its identity was confirmed by Gram staining, oxidase reaction and sugar fermentation tests. The m.i.c. of penicillin for this strain was determined by inoculating $0.02 \mathrm{ml}$ of the cell suspension $\left(10^{7}\right.$ colony-forming units $\mathrm{ml}^{-1}$ ) on to plates of solid medium containing penicillin at concentrations of $0.6,0.3$, 
$0 \cdot 15,0.04,0.01$ and $0.0025 \mathrm{mg} \mathrm{l}^{-1}$. Growth on medium without added penicillin was used as a control; results were recorded after overnight incubation.

Scanning electron microscopv. An agar block with $N$. gonorrhoeae colonies was cut from a plate culture and fixed with $3 \%(\mathrm{v} / \mathrm{v})$ glutaraldehyde in sodium cacodylate $(0.1 \mathrm{M})$ buffer $\mathrm{pH} 7.4$ for $2-3 \mathrm{~d}$. The block was then rinsed in distilled water and dehydrated in an acetone series of $30 \%, 40 \%, 50 \%, 60 \%, 70 \%, 80 \%, 90 \%$ and $100 \%$ for $10 \mathrm{~min}$ with each concentration, before transfer to a Polaron E-3000 critical point drying apparatus. The chamber was flushed with liquid $\mathrm{CO}_{2}$ to remove traces of acetone and left filled with liquid $\mathrm{CO}_{2}$ for $1 \mathrm{~h}$ during which time the temperature of the chamber was allowed to rise to $35^{\circ} \mathrm{C}$. In this period all the liquid $\mathrm{CO}_{2}$ changed through its critical point to the gaseous state. The $\mathrm{CO}_{2}$ gas was vented off very slowly and the dried agar block was mounted on a scanning electron microscope stub with Dag 915 (electrical conductivity silver paint). The specimen was then coated with gold in an Edwards S-150 sputter coater in an atmosphere of argon; the coating time was two periods of $2 \mathrm{~min}$ at $45 \mathrm{~mA}$. The specimen was viewed in a Philips EM500 scanning electron microscope operating at $15 \mathrm{kV}$ using viewing angles of $30^{\circ}$ and $45^{\circ}$.

Transmission electron microscopy. Neisseria gonorrhoeae colonies grown on GC agar were harvested and suspended in $3 \%(\mathrm{v} / \mathrm{v})$ glutaraldehyde in sodium cacodylate buffer $\mathrm{pH} 7.4$ for $1 \mathrm{~h}$, then centrifuged at $100 \mathrm{~g}$ for $10-15 \mathrm{~min}$. The deposit was washed three times in the buffer, fixed in $1 \%(\mathrm{w} / \mathrm{v})$ osmium tetroxide for $30 \mathrm{~min}$, washed twice with distilled water and stained with freshly prepared $2 \%(\mathrm{w} / \mathrm{v})$ uranyl acetate for $30 \mathrm{~min}$. After staining, the cells were washed twice in distilled water, and after centrifugation, the deposit was dehydrated through an alcohol series of $50 \%, 70 \%, 95 \%$ and twice through $100 \%$ (with suspension and centrifugation each time). The deposit was passed through two changes of epoxypropane, before transfer to a mixture of equal parts of epoxypropane and Araldite in which it was left overnight at room temperature. The specimen was centrifuged, the supernatant fluid being replaced with full-strength Araldite, and left at room temperature overnight before being embedded in Beam capsules using fresh Araldite. After polymerization at $60^{\circ} \mathrm{C}$ for $48 \mathrm{~h}$, sections (60-90 nm thick) were cut on a Reichert OM3 ultramicrotome and mounted on copper grids followed by staining with lead citrate solution (Reynolds, 1963). Specimens were examined in a Philips EM400 electron microscope using an accelerating voltage of $80 \mathrm{kV}$.

\section{RESULTS AND DISCUSSION}

On solid medium, the m.i.c. of penicillin was $0.15 \mathrm{mg} \mathrm{l}^{-1}$, growth occurring below this concentration. A penicillin concentration of $0.04 \mathrm{mg} \mathrm{l}^{-1}$ was considered subinhibitory, and growth on a medium with this concentration of antibiotic was chosen for electron microscopic studies.

From the effect of benzyl penicillin $\left(0.04 \mathrm{mg}^{-1}\right)$ in solid medium on colonies of gonococci, it was apparent that penicillin in solid medium did not have the same effect on every cell of the colony (Fig. 1a). Affected cells were elongated or swollen, whereas others in the same colony were normal, similar to those seen in a control colony of the same strain grown on GC medium without added antibiotic (Fig. $1 b$ ). A séction through a colony grown with $0.04 \mathrm{mg}$ penicillin $\mathrm{1}^{-1}$ (Fig. 1c) showed the differential effects of penicillin on cells at the apex and at the base of the colony; cells were either elongated, swollen or normal.

Electron micrographs of thin sections through a colony grown on medium containing penicillin at $0.04 \mathrm{mg} \mathrm{l}^{-1}$ (Fig. 1d), showed a differential effect of the antibiotic with some intact cells and others where the cell wall was affected by penicillin such that they either lysed or lost part of the cell wall and appeared swollen. In thin sections of control colonies grown on medium without added antibiotic (Fig. 1e) all the cells appeared normal.

The detailed electron microscopic studies on $N$. gonorrhoeae strain AN151 cultured with a subinhibitory concentration of penicillin revealed that the antibiotic-induced morphological

Fig. 1. Effect of benzyl penicillin in solid medium on Neisseria gonorrhoeae AN151. (a, c) Scanning electron micrographs showing colonies grown on GC medium containing a subinhibitory concentration of penicillin $\left(0.04 \mathrm{mg} \mathrm{I}^{-1}\right)$ : elongated $(\mathrm{E})$, swollen $(\mathrm{S})$ and normal $(\mathrm{N})$ cells are apparent. $(b)$ Cells with normal morphology in a colony grown on GC medium without added antibiotic. $(d)$ Thin section of cells from a colony grown in the presence of a subinhibitory concentration of penicillin showing swollen or partially lysed cells. $(e)$ Thin section of cells grown without the antibiotic. Magnifications are 1600 in $(a)$ and $(b)$ and 3200 in $(c)$. The bar markers represent $0.4 \mu \mathrm{m}$ in $(d)$ and $(e)$. 

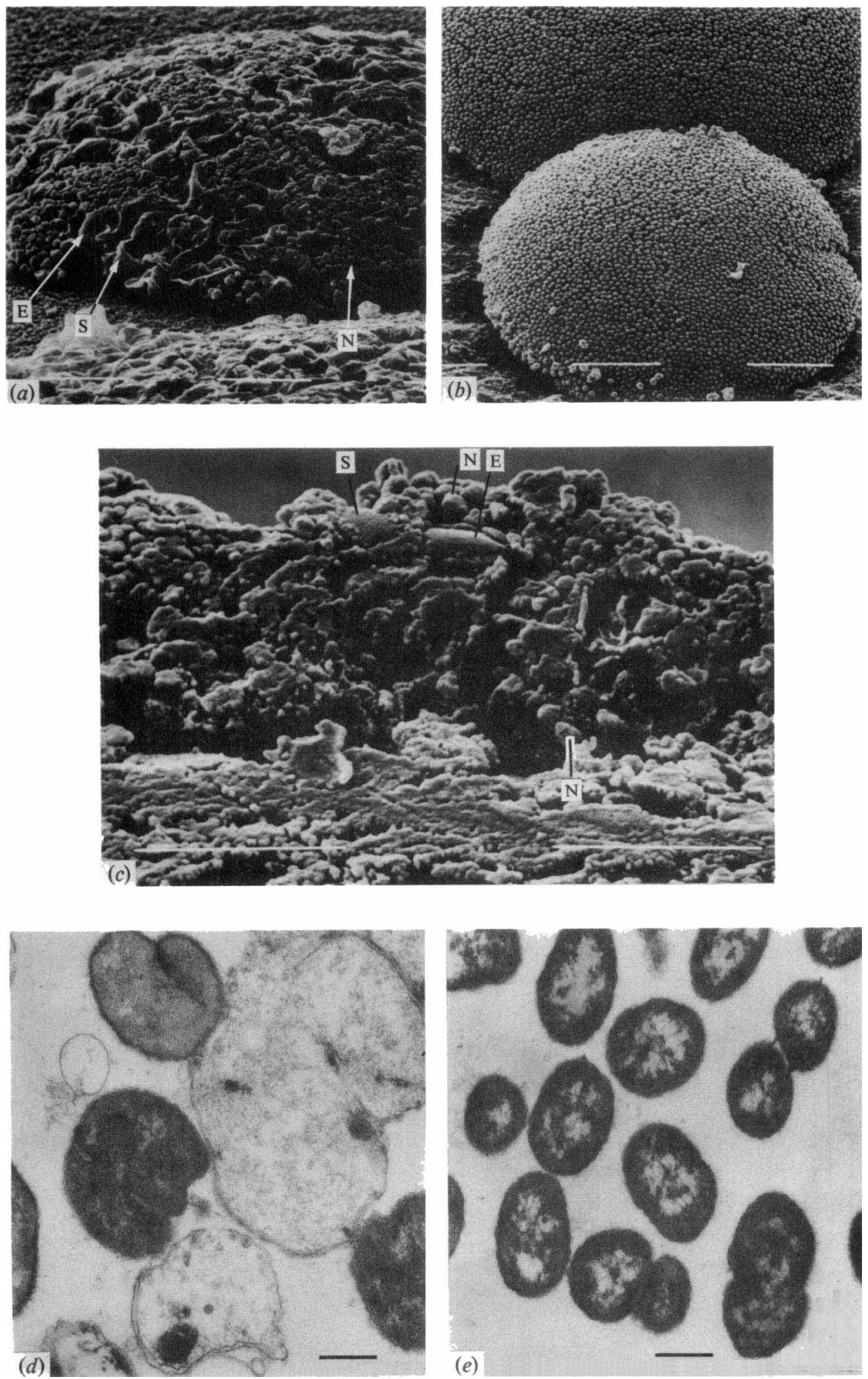
effects on cells in the colony were not uniform, probably due to the differences in the distribution of penicillin in different parts of the colony. Thus, it seems that determining the effect of penicillin on $N$. gonorrhoeae using solid media may not be an ideal system, and our earlier findings suggested that determination of m.i.c. and m.b.c. for strains of gonococci should be done using liquid medium.

We thank Mr Terry Durrant and the staff of Electron Microscopy (Division of Pathology), Medical School, University of Sheffield for technical help during this study. Jamal J. Jamil is supported by a study leave grant from Ministry of Health, Republic of Iraq.

\section{REFERENCES}

Blumberg, P. M. \& Strominger, J. L. (1974). Interaction of penicillin with the bacterial cell: penicillinbinding proteins and penicillin-sensitive enzymes. Bacteriological Reviews 38, 291-335.

Hugo, W. B. \& Russell, A. D. (1960a). Action of 6-amino-penicillanic acid on Gram-negative bacteria. Nature, London 188, 875.

Hugo, W. B. \& Russell, A. D. (1960 b). Quantitative aspects of penicillin action on Escherichia coli in hypertonic medium. Journal of Bacteriology $\mathbf{8 0}$, 436-440.

Hugo, W. B. \& Russell, A. D. (1961). Action of penicillin on Aerobacter cloacae. Journal of Bacteriology 82, 411-417.

JAMIL, J. J., HAFIZ, S. \& McENTEgaRT, M. G. (1981). The effect of benzyl penicillin on strains of Neisseria gonorrhoeae in liquid and solid media. Journal of Antimicrobial Chemotherapy 7, 201-204.

Kellogg, D. S., JR, Peacock, W. L., JR, Deacon, W. E., Brown, L. \& Pirkle, C. I. (1963). Neisseria gonorrhoeae. I. Virulence genetically linked to clonal variation. Journal of Bacteriology 85, 1274-1279.

LEDERBERG, J. (1956). Conjugal pairing of Escherichia coli. Journal of Bacteriology 71, 497498.

REYNOLDS, E. S. (1963). The use of lead citrate at high $\mathrm{pH}$ as an electron-opaque stain for electron microscopy. Journal of Cell Biology 17, 208-212.

Rogers, H. J. (1974). Peptidoglycan (mucopeptides): structure, function and variations. Annals of the New York Academy of Sciences 235, 29-51. 